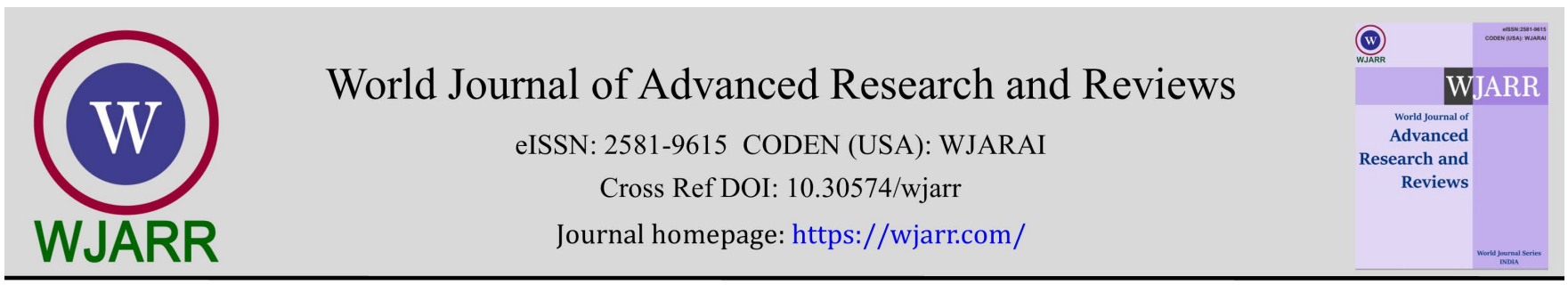

(RESEARCH ARTiClE)

Check for updates

\title{
Performance of soybean genotypes (Glycine Max L.) against Asian rust (Phakopsora Pachyrhizi Syd.) in Cameroon
}

Fabrice Christian Gbaporo Gbaporo 1, Alain Heu 2, Serge Bertrand Mboussi 3, Patrice Zemko Ngatsi 1, William Norbert Tueguem Kuate ${ }^{1}$, Sylvere Landry Lontsi Dida ${ }^{1}$, Stephane Kamtchoum ${ }^{4}$ and Zachée Ambang 1,*

1 University of Yaoundé 1, Faculty of Science, Laboratory of Biotechnology and Environment, Phytopathology and Plant Protection Research Unit, Yaoundé, Cameroon.

2 Technical Higher Training School, Department of Agriculture, Ebolowa, University of Yaoundé 1, Cameroon.

3 University of Douala, Faculty of science, Laboratory of Biotechnology, Douala, Cameroon.

${ }^{4}$ Institute of Agricultural Research for Development (IRAD), Yaoundé, Cameroon.

World Journal of Advanced Research and Reviews, 2021, 11(02), 020-030

Publication history: Received on 07 June 2021; revised on 27 July 2021; accepted on 30 July 2021

Article DOI: https://doi.org/10.30574/wjarr.2021.11.2.0318

\begin{abstract}
Asian rust caused by Phakopsora pachirhizi, which is a major constraint to production of soybean, causing $90 \%$ yield losses in field. Synthetic fungicides used to control this disease are environmentally degrading and have negative impact on the health of producers and consumers. The use of resistant soybean genotypes can be an effective control alternative. The aim of this work is to evaluate the tolerance of soybean varieties to Asian rust disease under natural conditions. Forty-three soybean varieties were screened using a completely randomized block design with three replicate. Incidence and severity of disease at 6, 8 and 10 weeks after sowing (WAS) and yields were evaluated. Results show that disease incidence of Asian rust was significantly higher in the local variety R3 (16.67\%; 29.63\%; 75.93\%) at 6, 8 and 10 WAS respectively. At 6 and 8 WAS severity of disease was higher in local variety R3 $(21.17 \%$ and $24.14 \%$ respectively). The variety TGX-2010-12F has the highest yield (1.17 t ha-1) than the local variety $\mathrm{R} 3(0.17 \mathrm{t}$ ha-1). Principal component analysis realized with incidence, severity of disease at 6, 8, 10 WAS and yield shows that 12 varieties are highly susceptible to Asian rust, 12 varieties are moderately resistant, and 19 varieties are susceptible. This study shows that Asian rust attacks all soybean varieties in the field. Moderately resistant varieties, can be advised to growers with appropriate protection methods or be subject to varietal improvement through genetic techniques.
\end{abstract}

Keywords: Screening; Varieties; Asian rust; Resistance; Glycine max; Yield

\section{Introduction}

Soybean (Glycine max L.) is an annual plant belonging to the Fabaceae family. Originally from East Asia, soybean is cultivated for its seeds which are very rich in proteins (30 to 40\%), lipids (20\%), carbohydrates (35\% including $20 \%$ fiber), minerals and vitamins (5\%) [1]. Proteins play a role in regulating blood cholesterol, thereby contributing to reducing the risk of contracting cardiovascular disease [2]. Most of the soybeans produced worldwide are crushed to be transformed either into cake for animal feed, into oil for human consumption or used as an agrofuel. After palm oil, soybean oil is the second most consumed oil in the world [3]. In addition, the plant's ability to fix atmospheric nitrogen contributes significantly to improving soil fertility [4].

\footnotetext{
${ }^{*}$ Corresponding author: Zachée Ambang

University of Yaoundé 1, Faculty of Science, Laboratory of Biotechnology and Environment, Phytopathology and Plant Protection Research Unit, Yaoundé, Cameroon.
} 
Soybeans are present in more than 80 countries around the world, with the United States being the main producer, with production in 2019 estimated at around 85.6 million tons (Mt), and followed by Brazil with around 60.54 Mt and Argentina with around $36.37 \mathrm{Mt}$, [5]. On a global scale, statistics show that soybean is the first seed legume cultivated in the world and the fourth most important legume cultivated and consumed in Cameroon after groundnut, cowpea and bean [6]. In Cameroon, soybean is grown in his five agro-ecological zones. Despite the slight increase in yields observed, in 2018 and 2019 (1.3926 t/ha to 1.4450 t/ha) its production remains relatively low (23058 tonnes) [5] in relation to demand.

In spite of its socioeconomic importance and nutrition, soybean farming is facing several problems that largely explain the low yields. These problems include low soil fertility, pests and diseases [7]. Among the diseases, the most important are fungal origin, particularly Asian rust caused by Phakopsora pachirhizi, which is a major constraint to production, causing yield losses of up to $90 \%$ [8]. Disease control in the field is most often subject to the use of chemicals that are environmentally degrading and have negatively impact on the health of producers and consumers [9]. The scarcity of data referring to the resistance of (newly introduced) soybean varieties to Asian rust disease deserves special attention as an alternative to chemical control. In Cameroon, work on the susceptibility of these soybean varieties to Asian rust is very poorly documented. Only information on the adaptability of the varieties is available [10]. Therefore, it would be interesting to screen the forty-three soybean varieties newly introduced in Cameroon against Asian rust disease. The hypothesis being tested is that among the screened varieties, there is one with resistance to Asian rust disease in natural conditions. The general objective of this study is to identify soybean varieties showing resistance under the influence of Asian soybean rust in the locality of Mfou in Cameroon.

\section{Material and methods}

\subsection{Materials}

\subsubsection{Study site}

The work took place on a fallow land of 2 years old from May 26 to September 15, 2020 in the locality of Mfou. This locality is the capital of the Department of Méfou-et-Afamba, located in the Central Region of Cameroon. The geographical coordinates recorded using a GPS Garmin is: $3^{\circ} 45^{\prime} 27.048^{\prime \prime}$ North latitude; $11^{\circ} 37^{\prime} 38.532^{\prime \prime}$ East longitude, altitude $\pm 701 \mathrm{~m}$. This locality belongs to the agro-ecological zone 5 known as the bimodal rainfall zone. The average temperature is $25^{\circ} \mathrm{C}$ and the average annual rainfall is $1500-2000 \mathrm{~mm}[11,12]$. The prevailing climate is of the Guinean type. The soils are ferralitic, acidic, clayey with a low nutrient retention capacity.

\subsubsection{Plant Material}

The experiment involved 43 soybean seeds varieties, including 38 exotic and 5 local varieties (Table 1). The exotic varieties are newly introduced through collaboration between the Institute of Agricultural Research for Development (IARD) and the University of Illinois at the United States. The local varieties are from the IRAD breeding of Foumbot (TGX-1835-10E; TGX 2007-8F) and Garoua (R3; R2; TGX 1448-2F) originating from the International Institute of Tropical Agriculture (IITA).

Table 1 Different soybean varieties and their origin

\begin{tabular}{|l|l|c|c|}
\hline Varieties & Source & Exotic/Local & Maturity (days) \\
\hline TGx2002-23DM & IITA (Zambia) & exotic & $90-100$ \\
\hline Afayak & CSIR-SARI (Ghana) & exotic & $90-100$ \\
\hline SoungPungun & CSIR-SARI (Ghana) & exotic & $90-100$ \\
\hline TGx2001-24DM & IITA (Zambia) & exotic & $90-100$ \\
\hline TGx2001-10DM & IITA (Zambia) & exotic & $90-100$ \\
\hline JENGUMA & CSIR-SARI (Ghana) & exotic & $90-100$ \\
\hline TGx2014-19FM & IITA (Zambia) & exotic & $90-100$ \\
\hline Maksoy 3N & U. Makerere (Uganda) & exotic & $90-100$ \\
\hline TGx2001-13DM & IITA (Zambia) & exotic & $90-100$ \\
\hline
\end{tabular}


World Journal of Advanced Research and Reviews, 2021, 11(02), 020-030

\begin{tabular}{|l|l|c|c|}
\hline TGx1987-62F & IITA (Nigeria) & exotic & $90-100$ \\
\hline Maksoy 2N & U. Makerere (Uganda) & exotic & $90-100$ \\
\hline S1140-5-4 & SeedCo (Zimbabwe) & exotic & $90-100$ \\
\hline DPSB 8 & KALRO (Kenya) & exotic & $90-100$ \\
\hline SNKGM011 & Sensako (South Africa) & exotic & $90-100$ \\
\hline SCS-1 & EIAR (Ethiopia) & exotic & $90-100$ \\
\hline S1150-5-22 & SeedCo (Zimbabwe) & exotic & $90-100$ \\
\hline Clark 63K & EIAR (Ethiopia) & exotic & $90-100$ \\
\hline TGx2006-3F & IITA (Nigeria) & exotic & $90-100$ \\
\hline TGx2008-4F & IITA (Nigeria) & exotic & $101-110$ \\
\hline SC Saga & SeedCo (Zimbabwe) & exotic & $90-100$ \\
\hline TGx1991-22F & DARS (Malawi) & exotic & $90-100$ \\
\hline R3 & IITA(Cameroun) & local & $110-120$ \\
\hline TGX-1835-10E & IITA(Cameroun) & local & $90-100$ \\
\hline R2 & IITA(Cameroun) & local & $110-120$ \\
\hline TGx-2001-8DM & IITA (Zambia) & exotic & $90-100$ \\
\hline TGx-2001-1DM & IITA (Zambia) & exotic & $90-100$ \\
\hline TGx-2002-1DM & IITA (Zambia) & exotic & $90-100$ \\
\hline TGX1485-1D & IITA (Nigeria) & exotic & $90-100$ \\
\hline TGX2004-10F & IITA (Nigeria) & exotic & $101-110$ \\
\hline TGX 2011-7F & IITA(Nigeria) & exotic & $90-100$ \\
\hline TGX 2010-3F & IITA(Nigeria) & exotic & $90-100$ \\
\hline TGX 2007-11F & IITA (Nigeria) & exotic & $101-110$ \\
\hline TGX 2004-3F & IITA(Nigeria) & exotic & $90-100$ \\
\hline TGX 2010-15F & IITA(Nigeria) & exotic & $90-100$ \\
\hline TGX 2011-3F & IITA (Nigeria) & exotic & $90-100$ \\
\hline TGX 2008-2F & IITA(Nigeria) & exotic & $101-110$ \\
\hline TGX 2004-13F & IITA (Nigeria) & $90-100$ \\
\hline TGX 2007-8F & IITA(Cameroun) & $90-100$ \\
\hline TGX 1448-2F & IITA(Cameroun) & $101-110$ \\
\hline TGX 2010-12F & IITA (Nigeria) & $90-100$ \\
\hline TGX 2002-14DM & IITA (Zambia) & exotic & 900 \\
\hline TGX 2001-14DM & IITA (Zambia) & liTA (Nigeria) & local \\
\hline TGX 2010-11F & & exotic & 900 \\
\hline
\end{tabular}




\subsection{Methods}

\subsubsection{Experimental design and culture conditions}

The experimental design was a completely randomized blocks with three repetitions. The blocks (22.5 $\mathrm{m} \times 5 \mathrm{~m})$ consisted of 43 plots or experimental units which represent the varieties. Each block is spaced by $1 \mathrm{~m}$ and $0.5 \mathrm{~m}$ paths separated the plots. The varieties are sown manually 3 days after ploughing, with a distance of $0.5 \mathrm{~m}$ between rows and $0.5 \mathrm{~m}$ between bunches (68 800 plant ha $^{-1}$ ). Each row consisted of 9 bunches, i.e. 18 plants per row. A sarclo-buttage was carried out manually at 3 and 6 weeks after sowing (WAS). No fungal treatments or fertilizers were applied during the experiment. The contamination of the plot was done naturally by the pathogen.

\subsubsection{Evaluation of the incidence and severity of Asian rust}

Plants per plot was counted and noted. Diseased plants were identified and counted per experimental unit. The incidence of the disease was determined every two weeks according to the usual formula in plant pathology described by Tchoumakov and Zaharova [13]

$$
I(\%)=\frac{\text { number of diseased plants }}{\text { Total number of plants per experimental unit }} X 100
$$

Table 2 Scale for estimating degrees of infection

\begin{tabular}{cc|l|l|}
\hline Code & Severity (\%) & Description & Grades \\
\hline 1 & $(0 \%)$ & Total absence of symptoms & Immune/Disease Free \\
\hline 2 & $(0.6-1.99 \%)$ & Infection occupying less than half the leaf area & Moderately Resistant \\
\hline 3 & $(2-6.99 \%)$ & Infection covering two-quarters of the leaf area & Moderately Susceptible \\
\hline 4 & $(7-17.9 \%)$ & Infection covering more than two-quarters of the leaf area & Susceptible \\
\hline 5 & $(18-41.9 \%)$ & Infection covering three - quarters of the leaf area & Highly Susceptible \\
\hline 6 & $(42-78.5 \%)$ & Infection covering more three - quarters of the leaf area &
\end{tabular}

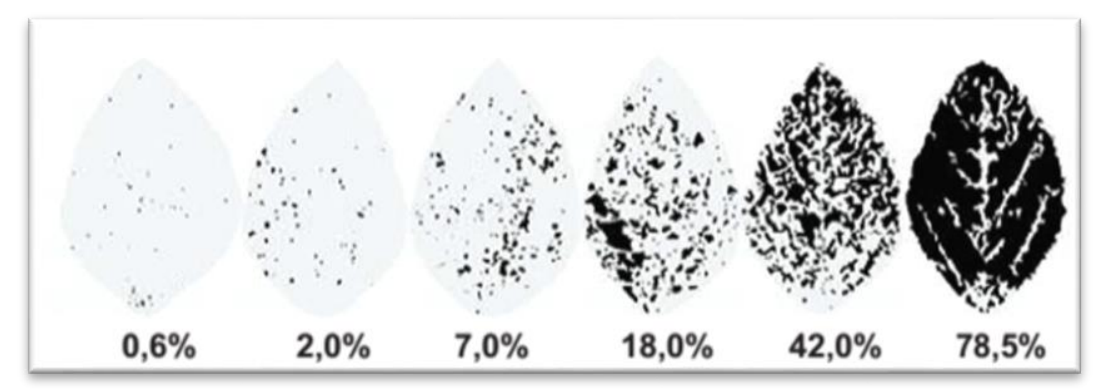

Figure 1 Diagrammatic scale of soybean (Glycine max) rust severity (percentage of diseased leaf area) [14]

The severity of the disease was taken every two weeks on ten plants labeled per treatment, the degrees of infection were attributed using the scale of 6 point (Fig.1) proposed by Godoy et al. [14] with some modification. The quantification of the disease was done by treatment and as a function of time. The severity of the disease was expressed by the formula described by Tchoumakov and Zaharova [13].

$$
\mathrm{S}=\sum(\mathrm{aX}) / \mathrm{n} \times 100
$$

Where: $\sum(\mathrm{ab})=$ is the sum of the multiplications of the number of diseased plants, $(\mathrm{a})=$ with the degree of corresponding infection, (b) = given in $\%, n=$ the number of diseased plants (Table 2 ). 


\subsubsection{Yield estimation of soybean varieties}

The mature and half-dry pods of ten seedlings labeled by variety were harvested, then oven-dried (Selecta brand) until a constant weight was obtained. After hulling, the seeds obtained were weighed using a balance trade mark Sotorius (precision 0.001). Varietal yields were calculated according to the formula of Svecnjak et al. [15].

$$
\text { Yield }(\mathrm{t} / \mathrm{ha})=\frac{\text { PGEp X N }}{\mathrm{S}} \mathrm{X} 10000
$$

Where: PGEp = weight of dry soybeans per plant, $\mathrm{N}=$ number of soybean plants per treated elementary plot, $\mathrm{S}=$ area of each elementary plot treated, $10000 \mathrm{~m}^{2}=1$ hectare

\subsubsection{Statistical analysis}

Data on the epidemiological parameters (incidence and severity) and the yield of the different varieties were organized using the EXCEL 2010 spreadsheet (Microsoft office). These data were subjected to one-way analysis of variance (ANOVA) using R software version 3.5.1. The multiple comparisons of means were performed using the Last significant difference (LSD) test at $P<0.05$ to separate them when the analysis of variance was significant. The principal component analysis and dendrograms were performed using the parameters incidence, severity and yield.

\section{Results}

\subsection{Incidence of Asian soybean rust on screened varieties}

Incidence of the disease of the 43 varieties observed during the data collection varies according to the varieties (Fig.2). At 6, 8 and 10 WAS $(P<0.001)$, the local variety R3 had the highest incidence of $16.67 \% ; 29.63 \%$; $75.93 \%$ respectively. It is followed by the variety S1150-5-22 with incidences of $12.96 \% ; 25.93 \%$ at 6 and 8 WAS respectively. Varieties AFAYAK, JENGUMA, MAKSOY2N, MAKSOY3N, S1140-5-4, TGX-2001-1DM, TGX-2001-80M and TGX-2007-11F have zero incidences at 6 WAS. In contrast, at 10 WAS, they had incidence of 16.67, 25.93, 50, 55.56, 37.04, 48.15, 46.30, and $59.26 \%$, respectively.

\subsection{Severity of Asian rust of screening varieties}

The severity of the disease observed during the different data collection varies according to the varieties (Fig.3). Significant differences $(P<0.001)$ were recorded between the severities of the different varieties over time. The local variety R3 had the highest severity of $21.17 \%$ and $24.14 \%$ respectively at $6 \mathrm{WAS}$ and $8 \mathrm{WAS}$, while at $6 \mathrm{WAS}$, the varieties AFAYAK, JENUMA, MAKSOY2N, MAKSOY3N, S1140-5-4, TGX-1448-2E, TGX-2001-1DM, TGX-2001-24DM, TGX-2001$80 \mathrm{M}$ and TGX-2007-11F had zero severity. At 10WAS the varietyTGX-2002-14DM had the highest severity of 59.26\% compared to the variety TGX-2001-1DM which had the lowest severity of $10 \%$

\subsection{Yield of screened soybean varieties}

Yield results for soybean varieties in natural infection conditions vary by variety (Fig.4). The analysis of variance found a significant difference between varieties $(P<0.05)$ on grain yields in $\mathrm{t} \mathrm{ha}^{-1}$. TGX-2010-12F $\left(1.17 \mathrm{t} \mathrm{ha}^{-1}\right)$, TGX-2010-3F $\left(0.78 \mathrm{t} \mathrm{ha}^{-1}\right)$ had the highest yields while R3 $\left(0.17 \mathrm{tha}^{-1}\right)$ and R2 $\left(0.19 \mathrm{t} \mathrm{ha}^{-1}\right)$ had the lowest yields. However, the variety TGX-2010-3F $\left(0.78 \mathrm{t} \mathrm{ha}^{-1}\right)$ and CLARK-63K $\left(0.779 \mathrm{tha}^{-1}\right)$ are not statistically different.

\subsection{Multivariate analysis}

\subsubsection{Principal component analysis}

S.6.WAS: severity six days after sowing; S.8.WAS: severity eight days after sowing; S.10.WAS: severity ten days after sowing; I.6.WAS: incidence six days after sowing; I.8.WAS: incidence eight days after sowing; I.10.WAS: incidence ten days after sowing. 
World Journal of Advanced Research and Reviews, 2021, 11(02), 020-030

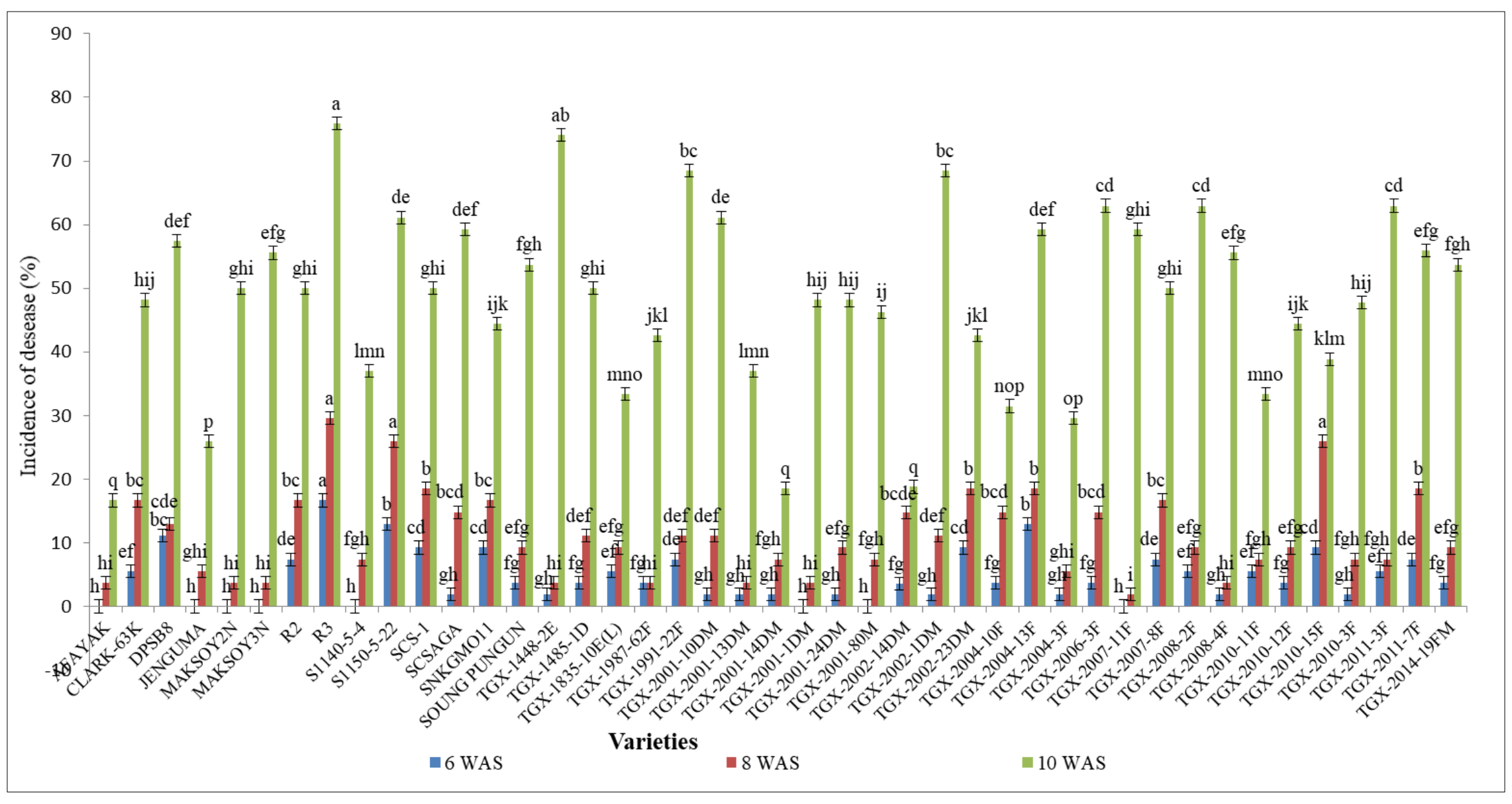

Figure 1 Incidence of Asian soybean rust in different varieties by time 


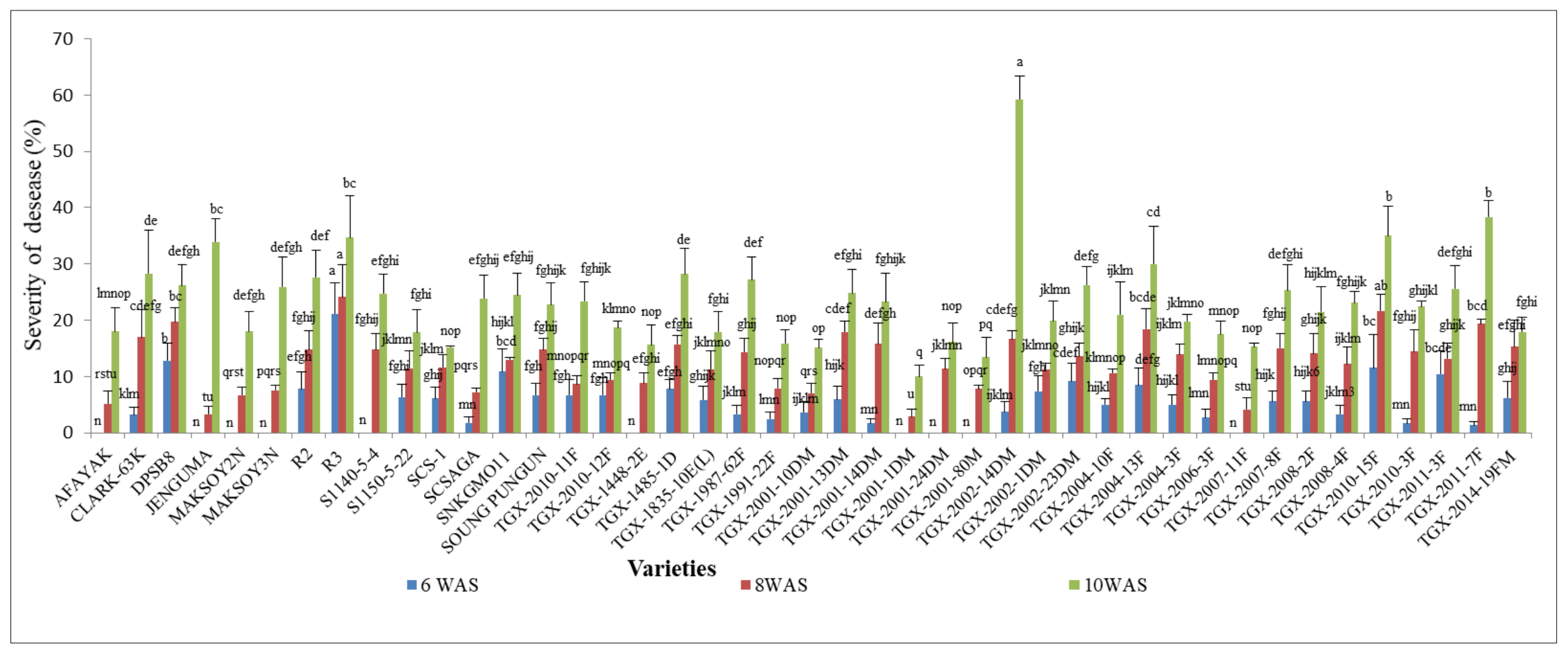

Figure 2 Severity of the Asian soybean rust on varieties by time 


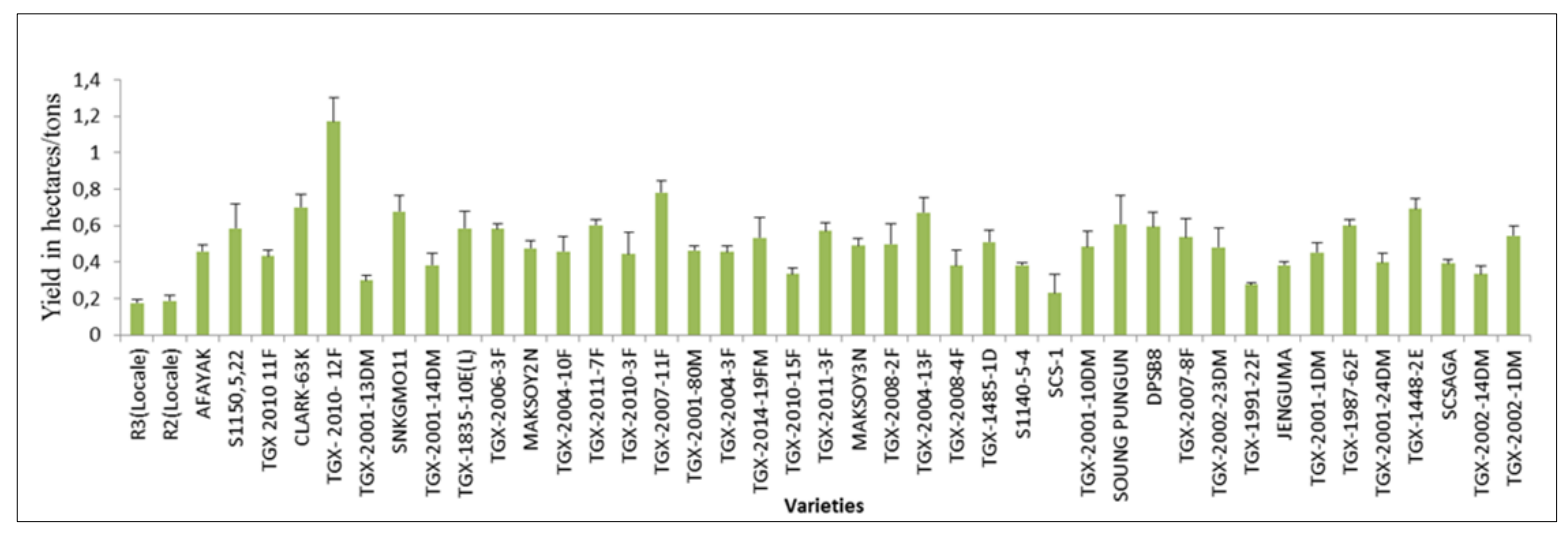

Figure 3 Yield of soybean varieties in natural infection condition

Principal component analysis (PCA) is used to group the screened soybean varieties on the basis of three variables namely incidence, severity and yield (Fig.5). The variables are well represented through the circle of correlations with a good rate of return of information on dimension $1(46,58 \%)$ and dimension $2(15.01 \%)$ for a total of $61.58 \%$. Some varieties including TGX-2010-12F, TGX-2010-3F CLARK-63K and TGX-2002-23DM are close in Yield with low susceptibility to Asian soybean rust disease. Other varieties are the intermediate varieties and finally the varieties that show low yields in relation to their susceptibility to the disease.
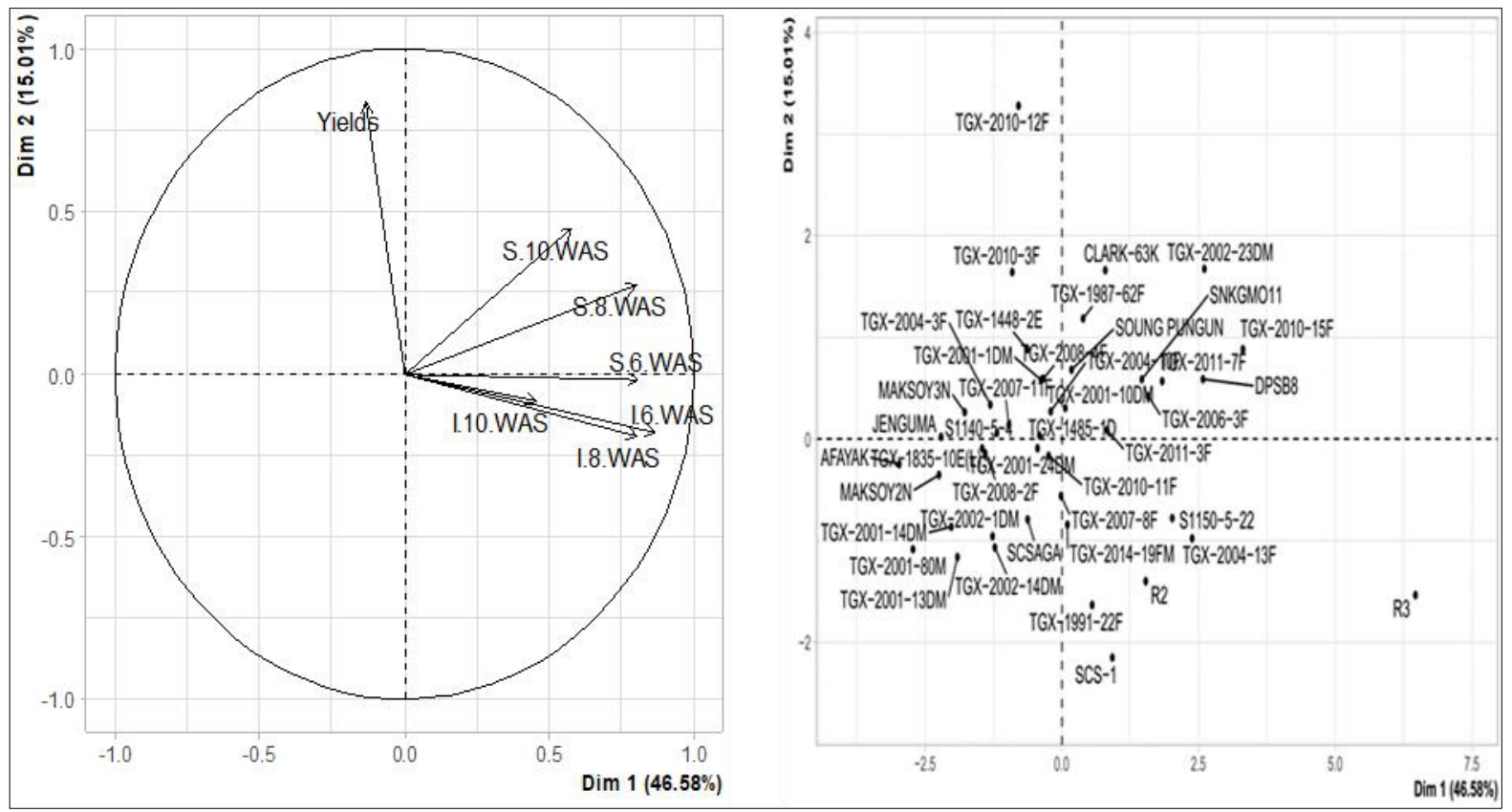

Figure 4 Principal Component analysis between soybean varieties and the studied parameters

\subsubsection{Clustering of varieties according to epidemiological parameters and yield}

Taking into account the different parameters of the study, namely incidence, severity and performance, a dendrogram was carried out (Fig.5). Three groups emerge from the classification. The first group consists of 12 varieties that are highly susceptible to Asian rust and have very low yields (R3, SCS-1, TGX-2002-23DM, R2, TGX-2014-19FM, TGX-2011$7 \mathrm{~F}$ etc. The second group consists of 12 varieties which are moderately resistant to Asian rust and have very high yield. Among these are the varieties TGX-2010-12F, TGX-2010-3F CLARK-63K and TGX-2002-23DM, TGX-2007-11F, TGX2008-4F, SOUNG POUNGUN. The third group consists of the varieties SCSAGA, MAKSOY2N, MAKSOY3N, TGX-2002-80M, AFAYAK etc. which are susceptible and have a low yield. 


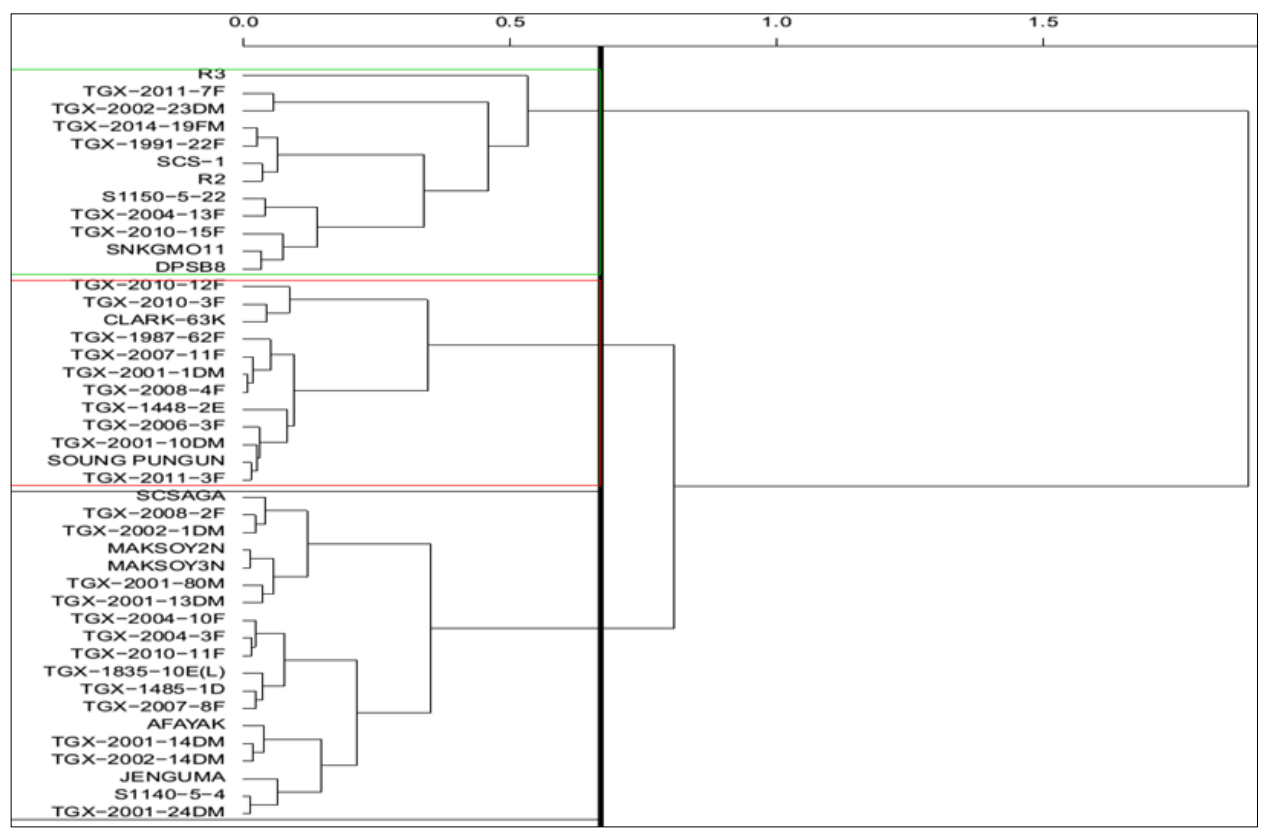

Figure 5 Dendrogram of screening varieties according to incidence, severity and yield

\section{Discussion}

Soybean is cultivated for its seeds that are very rich in protein, fat and trace elements [2]. Soybeans face Asian rust disease in the field, which can cause yield losses of up to $90 \%$ if no sanitary action is taken [8]. There is an extensive literature describing the use of synthetic pesticides to mitigate the effects of this disease on yield. This study predicts that newly introduced soybean varieties in Cameroon that have not been previously studied compared to three local varieties most commonly grown by farmers may have different susceptibility to the disease in the field. Varietal selection is most often used to control crop diseases and pests [16,17]. As a result, the identification of soybean varieties with yield resistance to Asian soybean rust has been studied.

Results obtained on the incidence and severity of Asian soybean rust disease on the 43 varieties show that the disease varies between varieties over time. R3 and TGX-1448-2E had the highest incidence compared to the other varieties. The variation in incidence by variety over time could be due to the availability of inocula and different host-variety interactions. Mahesha et al. [18] working on the evaluation of 204 soybean genotypes under controlled conditions against major diseases reported several genotypes with multiple sources of resistance. This could also be due to favorable climatic conditions (increased wind intensity, rainfall) that favour successive natural inoculation. Indeed, Luck et al. [19] demonstrated that the increase in climatic and meteorological events accentuates the dispersion of phakospora pachyrhizi spores (the causal agent of rust) in the field. The high incidence in some varieties compared to others could be due to the susceptibility of these varieties compared to others, or to environmental conditions as presented by Schilling [20].

With regard to severity, the highest values are obtained in varieties TGX-2002-14DM and TGX-2011-7F, in contrast to varieties AFAYAK, JENUMA, MAKSOY2N, MAKSOY3N, S1140-5-4, TGX-2001-1DM, TGX-2001-24DM, which show zero incidence and severity at 6 WAS. The variation in severity from one variety to another can be justified by the virulence of the strains and environmental conditions as disease development results from the dynamic interaction between the host plant, the pathogen and the environment [21]. The high severity of Asian rust in some varieties could also be due to the variability of pathogenic strains of Phakospora pachyrhizi. According to Ddamulira et al. [22], pathogen change is one of the causes of different strains in different agro-ecological zones. The fact that AFAYAK, JENUMA, MAKSOY2N, MAKSOY3N, S1140-5-4, TGX-1448-2E, TGX-2001-1DM, TGX-2001-24DM varieties have zero severity at 6 WAS could be due to the presence of disease resistance genes in their genotypes. Indeed, work on the identification of multiple sources of disease resistance in cultivated and wild soybean has been undertaken by many researchers $[23,18,24]$.

The yields obtained vary according to the varieties. The low yields recorded in general and in particular in varieties R3 and R2 could be due to disease pressure that would reduce the leaf area of the plants and consequently reduce photosynthetic activity (Ngueguim [25,26]. It could also be related to the improved characteristics of the different 
varieties, which would explain why some varieties have high (TGX-2010-12F) and some low yields (TGX-2010-12F). Senan et al. [27] working on the performance of six tomato cultivars against spoon leaf yellowing, bacterial wilt and root-knot nematodes showed that a difference in yield between varieties in the same season is due to the variety itself.

The dendrogram carried out according to the three parameters (incidence, severity and yield) allowed to group them in moderately resistant, susceptible and highly susceptible varieties. This could be justified by the approximation of the averages of the incidences, severities and yields of the different varieties. These results are different from those of Bachkar et al. [28] Zade et al. [29],which working on Screening of 36 soybean genotypes against mosaic virus, on Screening of 33 genotypes against alternaria leaf spot disease respectively obtained four group(resistant, moderately resistant moderately susceptible and susceptible) and those of Chavan et al.[30].which working on Screening of 40 soybean genotypes against Colletotrichum truncatum group them in moderately resistant, moderately susceptible ,susceptible and highly susceptible.

\section{Conclusion}

The main objective of this study was to evaluate the susceptibility of 43 soybean varieties under natural infection conditions against Asian soybean rust on yield. It was found that variety R3 and TGX-1448-2E had the highest incidence. VarietiesTGX-2002-14DM andTGX-2011-7F show the highest severity to Asian rust disease at 10WAS; unlike varieties AFAYAK, JENUMA, MAKSOY2N, MAKSOY3N, S1140-5-4, TGX-1448-2E, TGX-2001-1DM, TGX-2001-24DM which have zero incidence and severity at 6WAS. Varieties TGX-2010-12F (1.17 t/ha), TGX-2010-3F (0.78 t/ha) have the highest yields, unlike variety R3 (0.17t/ha.). The dendrogram has allowed to group them into highly susceptible (R3, SCS-1), moderately resistant (TGX-2010-12F, TGX-2010-3F) and susceptible (AFAYAK, TGX-1835-10E) varieties. These moderately resistant varieties, can be advised to growers with appropriate protection methods or be subject to varietal improvement through genetic techniques.

\section{Compliance with ethical standards}

\section{Acknowledgments}

Thanks to Institut of Agricultural Research for Development (IARD) for the supplying of varieties, to the laboratory of Biotechnology and Environment, Phytopathology and Plant Protection of de University of Yaoundé 1 and all Authors for their contributions.

\section{Disclosure of conflict of interest}

The authors: Gbaporo Gbaporo F.C, Heu A, Mboussi SB, Ngatsi Zemko P, Kuate TueguemWN, Dida Lontsi SL, Kamtchoum $\mathrm{S}$, Ambang zachée declare that they have no conflict of interest.

\section{References}

[1] Jacques BB. SOYBEAN. 2010. www.sante-vivante.fr 1/21

[2] Collomb V, Mayor M. Soybeans, the queen of vegetable? Geneva School of Health, Dietetics. $2007 ; 4$.

[3] STATISTA. Consumption of vegetable oils worldwide from 2013/14 to 2019/2020, by oil type; 2020

[4] Saïdou A, Kossou D, Acakpo C, Richards P, Kuyper WT. Effects of farmers' practices of fertilizer application and land use types on subsequent maize yield and nutrient uptake in Central Benin. Int. J. Biol. and Ch. Sci. 2012; 6(1): 363-376.

[5] FAO. FAOSTAT Data base results. Food and Agriculture Organization (FA0). Rome: 2020 Faostat. https://Faostat.fao.org.

[6] Kouebou CP, Achu M, Nzali S, Machawe C, Bonglaisin J, Kamda A, Djiele P, Yadang G, Ponka R, Ngoh NG, Nkouam G, Teugwa C, Kana Sop MMA. Review of composition studies of Cameroon traditional dishes: Macronutrients and minerals. Food Ch. 2013; 17.

[7] Wagara IN, Mwang OAW, Kimenju JW, Buruchara RA, Kimani PM. Reaction of selected common bean genotypes to physiological races of Phaeoisariopsis griseola occurring in Kenya. Afri. Crop Sci. J. 2011; 19 (4): 343 - 355. 
[8] Giller KE, Dashiell KE . Glycine max (L) Merill. Fiche de protabase. In: Van der Vossen, HAM, Mkamilo, GS (Eds) PROTA (Plant Ressources of Tropical Africa/ Ressources Végétales de l'Afrique Tropicale). Wageningen, PaysBas 2007; 17.

[9] Ben-Dov Y, Hogson C. Soft Scale Insects: Their Biology, Natural Enemies and Control. E. Sci. Am. 1997.

[10] USAID. Soybean Innovation Lab to introduce tropically-adapted soybean to several Pan-African Trials. 2019.

[11] Santoir C, Bopda A. Regional Atlas South Cameroon. Office for Scientific Research Overseas, Paris (France). 1995.

[12] Fomekong A, Messi J, Kekeunou S, Tamesse JL. Development, morphology and reproduction of Coridius xanthopterus, pest of cucumbers Cucumeropsis mannii in southern Cameroon. Ent. Faun. 2010; 62: 153-163.

[13] Tchoumakov A, zaharova. Statistic of disease development.Disease damages caused in crop production. Agroprom Izdat, Moscou. 1990; 53.

[14] Godoy C, Koga LJ, Canteri MG. Diagrammatic scale for assessment of soybean rust severity. Fitopatologia Brasileira. 2006; 31: 063-068.

[15] Svecnjak Z, Varga B, Butorac J. Yield Components of Apical and Subapical Ear contributing to the Grain yield Responses of Prolific Maize at High and Low Plant Populations. J.of Agro. And Crop Sci. 2006; 192: $37-42$.

[16] Acquaah G. Principes of plant genetics and breeding.1st (Ed).Blackwell publishing, malden.USA. 2007; PP 109120

[17] Ngatsi ZP, Ndongo B, Kutnjem D, Djieto-Lordon C. Crop genotype and stem cutting portion affect infestation pressure of the cassava root scale Stictococcus vayssierei Richard (Hemiptera: Stictococcidea) in a rainforest in Cameroon. Phytoparasitica. 2020; 48: 629-641.

[18] Mahesha B, Patil PV, Nandini B. Identification of multiple disease resistance sources in soybean. Crop Res. 2009; 37: 213- 216.

[19] Luck J, Spackman M, Freeman A, Trębicki P, Griffiths W, Finlay K, Chakraborty S. Climate change and diseases of food crops. Plant Pathol. 2011; 60: 113-121.

[20] Schilling R. Peanuts in tropical Africa.15th Ed. Maisonneuve ET Larose rue Victor Cousin, F 75005 PARIS. 1996.

[21] Adhikari TB, Mew TW, Teng PS. Progress of bactérial blight on rice cultivars carrying différent Xa geness for resistance in the field. Plant Dis.1994; 78: 73-77.

[22] Ddamulira G, Mukankusi C, Ochwo-Ssemakula M, Edema R, Sseruwagi P, Gepts P. Distribution and Variability of Pseudocercospora griseola in Uganda. J.agri. sci. 2014 6(6): 16-29.

[23] Mahesha B, Patil PV. Evaluation of soybean genotypes for multiple disease resistance. Soy. Res. 2007 ; 5: 7 5-79.

[24] Ingle YV, Chandankar GD, Patil P, Patil CU. Evaluation of advance lines of soybean for resistance to major diseases under natural field condition. Ind. J. Agri. Res. 2016; 50(1): 84-87.

[25] Djeugap FJ, Mefire M H, Nguefack J, Ngueguim M, Fontem DA. Varietal effect and fungicide treatment on the severity of angular spot disease and the yield of common bean (Phaseolus vulgaris L.) in West Cameroon. Int. J. Biol. and Ch. Sci. 2014; 8(3): 1221 - 1233.

[26] Ngueguim M, Mekontchou T, Fobasso M, Nounamo L. Influence of time of planting on yield and grain quality of bean genotypes grown on an andosol in the Western Highlands of Cameroun. Afri. Crop Sci. J. 2011; 19(4): 247254.

[27] Senan S, Mamadou D, Daouda D, Tschannen A, Girardin O. Performance of six cultivars of Lycopersicon esculentum Mills tomatoes against leaf spoon yellows, bacterial wilt and root-knot nematodes 1. Sci. Nat. 2007; 4(2): 123 130 .

[28] Bachkar CB, Balgude YS, Shinde PB, Deokar CD.Screening of soybean genotypes against soybean mosaic virus under natural and glass house conditions. Int. J. Chi. Sturdies. 2019; 7(1): 2267-2269

[29] Zade SB, Ingle YV, Ghuge AS, Wasule DL. Screening of soybean genotypes for resistance against alternaria leaf spot disease. J. Sci.Agri. And Eng. 2018; (8): 198-199.

[30] Chavan SS, Shinde DA, Kadam AM. Screening of soybean genotypes against Colletotrichum. J. pharma. And phyto. 2018; $1:$ 2972-2974. 